\title{
The climate to get things done
}

\section{Despite huge obstacles, political forces in Washington may finally get greenhouse-gas legislation moving, says David Goldston.}

ast week, in his first address to Congress, President Barack Obama laid out an - ambitious agenda that includes tackling the fiscal 2010 budget, financial reform, health insurance, education, Social Security and Medicare, and greenhouse-gas restrictions. Of these daunting issues, climate change may be the most complex and problematic - both politically and intellectually.

Some of the challenges are obvious: no other issue entails trying to eliminate a fundamental building block of the industrial economy like carbon-based fuels, or purposely raising the price of a basic commodity such as energy. Passing a bill to accomplish that would require Herculean efforts, even without a worldwide economic meltdown.

But the hurdles for enacting a climate law are even higher because there has been little public discussion about a bill, and the issue ranks low on the public's list of concerns. During the presidential campaign, both candidates mentioned climate change only in passing - just enough for those already concerned to note the nod in their direction - and the media didn't press the matter because the candidates agreed on the need for action. Obama has called for climate legislation in several speeches since his election, but his remarks have been lost in the noise of the economy screeching to a halt.

Congress itself is equally unprepared. Major legislation generally requires several years of engaged discussion and passage of more minor efforts to become law. That's how the political and substantive puzzles got worked out with, for example, civil rights and clean air and water legislation. But Congress has not yet truly got its hands dirty on climate legislation. The Senate has had only limited debate on bills that had no chance of passing; the House of Representatives has never even moved a climate bill through committee.

Scientific uncertainties are likely to complicate the picture. Up to now, science has generally figured in the climate debate in a simple and simplistic fashion: conservatives deny the ever-growing scientific consensus that man-made climate change is real, and

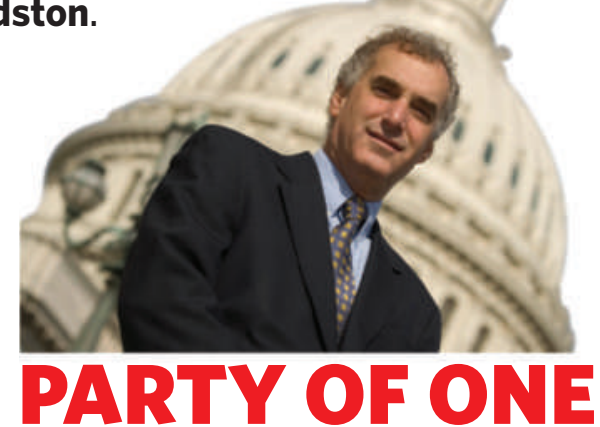

proponents of action respond by making it sound as if all scientific questions about climate are resolved. But in a fully fledged climate debate, much tougher questions will have to be asked - questions about what level of emission cuts over what time period will be needed to stave off what kinds of damage. Scientific answers to those questions are much less clear, and science alone will not be able to guide legislators, as decisions on how to handle uncertainty and risk are fundamentally matters of political values.

Other countries' track records are not promising. The Australian parliament could block Prime Minister Kevin Rudd's cap-and-trade programme, which is under attack from all quarters as details become known. And a proposed carbon tax helped sink the opposition in last year's Canadian elections.

So, against this bleak backdrop, have those predicting action on climate change in this US Congress too willingly suspended their disbelief? Probably not. There are, for the first time, strong factors militating in favour of legislation. The most important is the commitment of key political leaders, starting with the president. No previous president has risked political capital on the issue, but Obama included specific targets for greenhouse-gas reduction in the budget outline he released last week.

Also important is a change of committee chairs in the House. The committee that oversees climate legislation is now led by Henry Waxman (Democrat, California), a proficient legislator and the first avid proponent of climate action to hold that seat. Waxman has promised to get a climate bill out of committee by the end of May, leading one environmental lobbyist to remark, only half jokingly, "The Waxman staff doesn't have time to get something to eat."

Obama and his allies will have to struggle, though, to cobble together the 218 votes in the House and 60 in the Senate needed to pass a bill. Divisions are regional as much as partisan, with members from coal-mining and coal-burning areas especially hard to win over. A common parlour game in Washington is figuring out how to get the requisite number of votes, and no one is there yet. Lobbyists from all sides are leaning heavily on members who seem undecided - which includes more than a quarter of the members of the House.

One change in the political climate that may make it easier to garner votes is the greater openness to government regulation in the wake of the financial crisis. Support for climate-change legislation depends as much on attitudes towards government as it does on opinions about global warming. But those attitudes remain in flux; Obama was careful in his speech to Congress to forswear 'big government' and to laud private enterprise even as he called for new federal programmes. The lingering unease about government may create a tactical dilemma for climate-bill sponsors. Waxman's inclination has been to produce as strong a bill as possible - and to encourage pressure from his left - on the theory that the bill will be weakened through the legislative process. But too strong an initial bill in this environment could scare away needed votes.

The devil will be in the detail; climatechange bills in the abstract won't win enough converts. Picking up votes might involve cutting countless deals to address members' local interests - or the process could end up yielding an entirely different bill. Ideas that have been viewed as politically untenable - such as a carbon tax - are already gaining some support as climate legislation becomes a genuine possibility, and the headaches inherent in negotiating a cap-and-trade system could push more members into the tax camp. A few years ago, the idea of having the government auction at least some carbon credits (rather than give them out for free) seemed like the pipe dream of a few economists, but now it's a feature of almost every climate bill. And rebating all of the auction (or tax) revenues is an idea that is gaining steam.

The path to a climate bill is likely to be an obstacle course on which obstructions appear or change position without notice. But remarkably, it looks at last like a course that may be played through to the finish line.

David Goldston is a visiting lecturer at Harvard University's Center for the Environment. Reach him at partyofonecolumn@gmail.com. 